\title{
Evaluate the Accuracy of Fargas and BLM Models for Identification of Erosion Intensity
}

\author{
Naser Abdi \\ Department of Geology, Ahar Branch, Islamic Azad University, Ahar, Iran \\ Email: Naser182000@yahoo.com
}

How to cite this paper: Abdi, N. (2016) Evaluate the Accuracy of Fargas and BLM Models for Identification of Erosion Intensity. Open Journal of Geology, 6, 1457-1468. http://dx.doi.org/10.4236/ojg.2016.611103

Received: September 13, 2016

Accepted: November 25, 2016

Published: November 28, 2016

Copyright $\odot 2016$ by author and Scientific Research Publishing Inc. This work is licensed under the Creative Commons Attribution International License (CC BY 4.0).

http://creativecommons.org/licenses/by/4.0/

\begin{abstract}
Erosion process not only changes the land use to badlands, but also produces sediments that are dumped in the dam reservoirs, reduces the reservoir volume and finally makes it useless. So, it is necessary to do study on erosion intensity and the sediment production evaluation for which there are some methods and models. The experimental Fargas and BLM models are largely used for this issue, in Iran as well as many other countries, separately or together based on the data availability. These studies results are as data for sediment supply estimation in different watershed management studies. So, the result accuracy is important for determination of sediment occurrence. This study evaluates these models' results accuracy, in order to find the limitations and any solutions. Therefore, these two models were used and run in the same area, Aghbolagh drainage basin, Iran; the results were compared and evaluated. These models are based on some factors like rock type, drainage density, surface erosion and litter cover. The study includes field and laboratory analysis. The data were combined in GIS software and processed. The results reveal that, Fargas model predicts $3.67 \%, 14.26 \%$ and $81.06 \%$ of the area susceptible for high, severe and very severe erosion respectively; whilst, referring to BLM model outcome, $42.96 \%$ area has high sensitivity; $42.96 \%$ and $24.94 \%$ of the area have high and severe sensitivity for erosion, respectively. Furthermore, both models show same severity for around $18 \%$ of the study area. So, for these two models results very low similarities are concluded, which could be an indication of low reliability of the results, especially when they are used separately without any combination or comparison. Finally, it is recommended to use both of them together, or use another method beside each mentioned models.
\end{abstract}

\section{Keywords}

Erosion, Fargas, GIS, BLM, Sediment

\section{Introduction}

Erosion is a type of soil and rock weathering in which superficial layer is worn away 
through the action of glaciers, wind and water [1]. Although both soil and rock erosion are important, cultivation and life system soil erosion is more important, and makes social and economic problem and ecosystem changes [2] [3] [4].

Erosion monitoring is more effective than control of sediment using different methods. By detecting different erosion problems and classifying the area into different levels of susceptibility to erosion, it will be possible to use cost effective erosion control measurements [5].

Different erosion types like rill, gully, stream and channel are used for erosion severity and sediment production intensity from which gully erosion is more important, as it is occurred in the last stages of erosion progress, indicating high sediment production, but its study has been limited recently [6]. Whilst, study on gully erosion based on historical evidence, photology or remotely sensed images, is very practical. The result is also very applicable, as there is a strong correlation between the length and volume of the gully [7].

Drainage area of any basin is assumed as its sediment source, so the area is mapped and classified into erosion susceptive aprons to make remedial programs in order to reduce the erosion intensity, decrease soil erosion and overcome to sediment production and transform to dam reservoirs. This study uses different factors such as lithology, drainage pattern, steep slopes, erosion types and land use, to map and classify the drainage area using different models, and make comparison for the results.

\section{Study Area}

The $78.2 \mathrm{Km}^{2}$ study area is located in the northern Hashtrood City, between $37^{\circ} 28^{\prime} 51^{\prime \prime} \mathrm{N}$ $37^{\circ} 36^{\prime} 39^{\prime} \mathrm{N}$ and $46^{\circ} 59^{\prime} 59^{\prime \prime} \mathrm{E}-47^{\circ} 05^{\prime} 36^{\prime \prime} \mathrm{E}$ (Figure 1) with 2110 and $1668 \mathrm{~m}$ above sea level maximum and minimum elevations respectively. Average precipitation is $325 \mathrm{~mm}$, and could be assumed as cold semiarid. The main land use, 82 percent of the study area, is dry farm.

Geological studies illustrate the area has rarely been affected by tectonic forces, and sedimentary rocks are the predominant lithology. Unconsolidated conglomerates, sandy marls and alluvial sediments cover $81 \%$ of study area, which cause high potential for erosion.

\section{Methodology}

Two empirical methods, Fargas and BLM were used in this study to identify the critical sediment resources. The first one as a qualitative method which was developed by Fargas et al. [8] was initially used in $1500 \mathrm{Km}^{2}$ area watershed of the Joaquin Costa reservoir (NE Spain). This method uses reliable but limited parameters of lithology and drainage density which is rated according to erosion class. It is supposed that too less factors are easy to obtain, but could be the weak point.

The second one, BLM methodology is also applicable method for sediment risks evaluation. This technique uses seven factors, and the results are classified according to five major erosion classes. If these factors study carefully, the result will be reliable. 


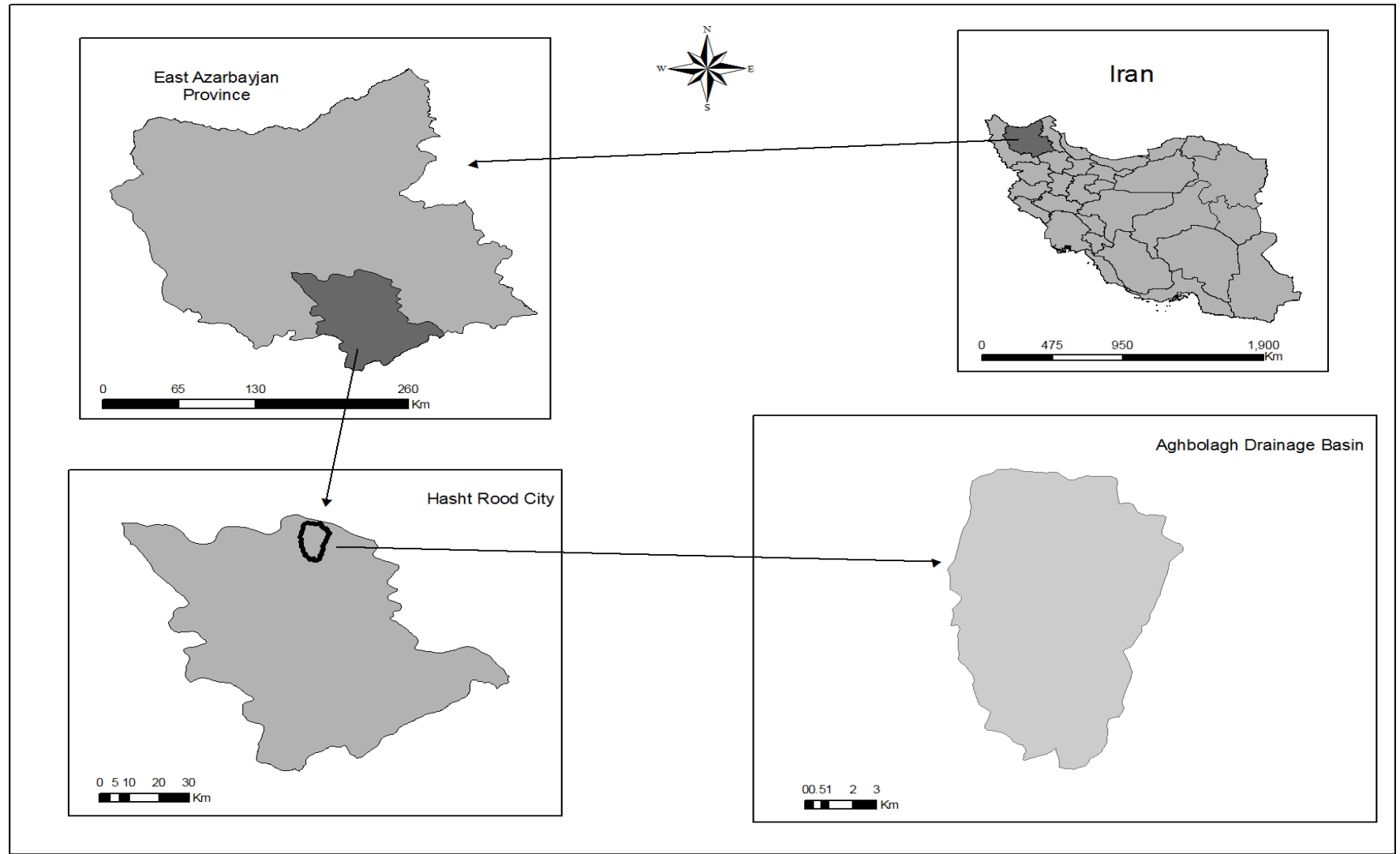

Figure 1. Location of study area.

\section{Discussion}

Two main models, Fargas and BLM, which are generally used for erosion assessment and soil conservation planning, were used to categorize the erosion intensity, erosion risk assessment, sediment production and critical sediment resources detection. Finally the results of above mentioned methods were appraised in comparison with each other and the similarities were recognized.

\subsection{Fargas Model}

The Fargas model is based on two main factors, lithology and drainage density. So, these factors are prepared as geological maps, and used in GIS software (Figure 2) and each unit area was calculated as percentage of total area (Table 1). This study uses geological map which was prepared based on detail field study as well as laboratory analysis, considering its importance. According to the map and Table $1, \mathrm{Q}^{\mathrm{t} 2}$ geological unit, composing of terrace alluviums which have high resistance index (erosion susceptible) covers about $46.5 \%$ of the area, whilst the hard rocks of gr, $\mathrm{O}_{\mathrm{r}}, \mathrm{E}_{\mathrm{va}}$ and $\mathrm{E}_{\mathrm{a}}$ have frequency of 14.26, 0.68, 0.68 and 3.67 percent, respectively. $\mathrm{Qpl}^{\mathrm{c}}, \mathrm{Qpl}^{\mathrm{m}}$ and $\mathrm{Q}^{\text {al }}$ are other soft lithological units with 4.7, 27.56 and 2.21 percentage, correspondingly.

The drainage density, the second main factor of this model, was prepared based on the detailed topography maps (Figure 3); then, erosion class which is attached to an 


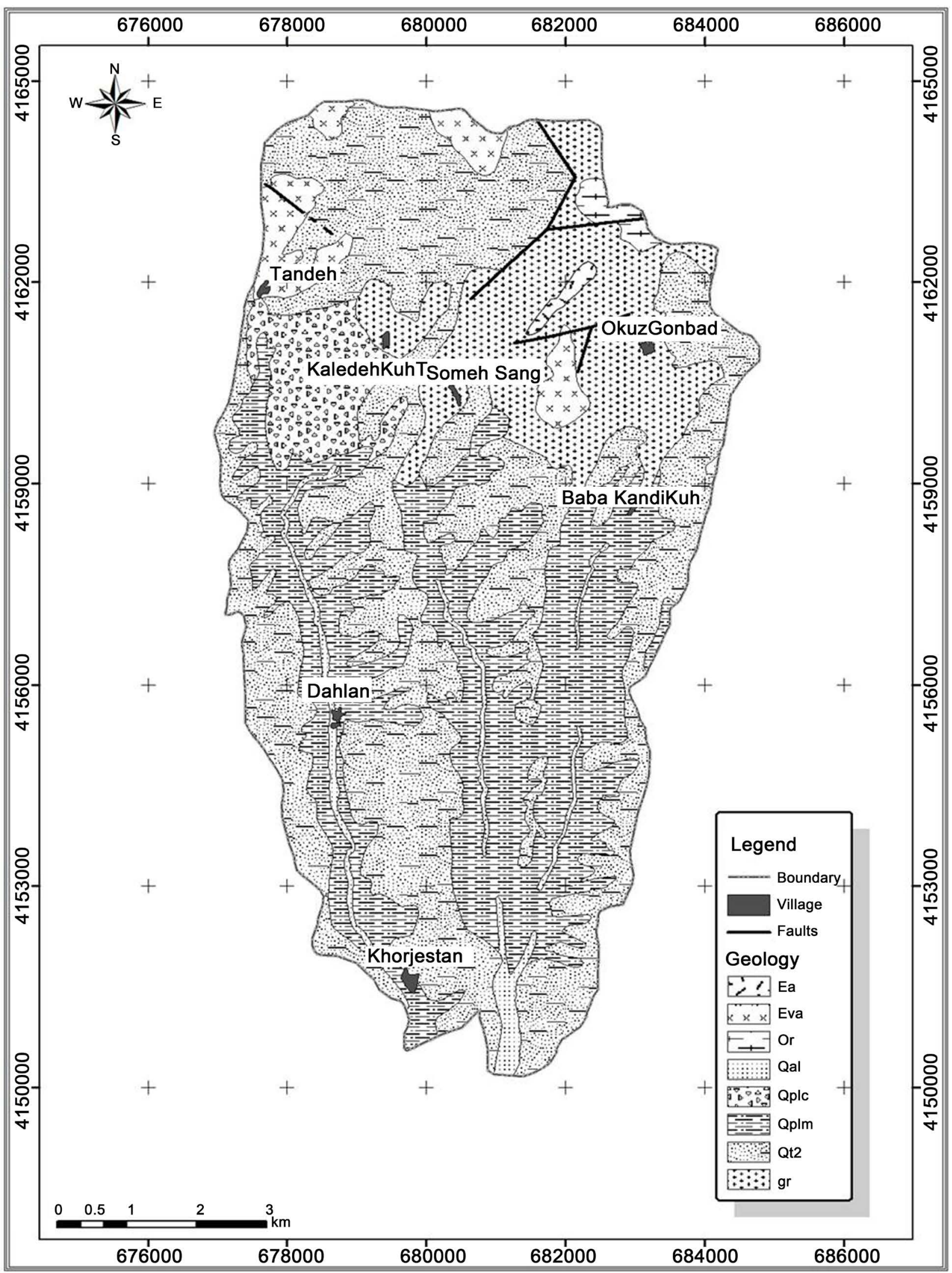

Figure 2. Geological map of the study area. 
N. Abdi

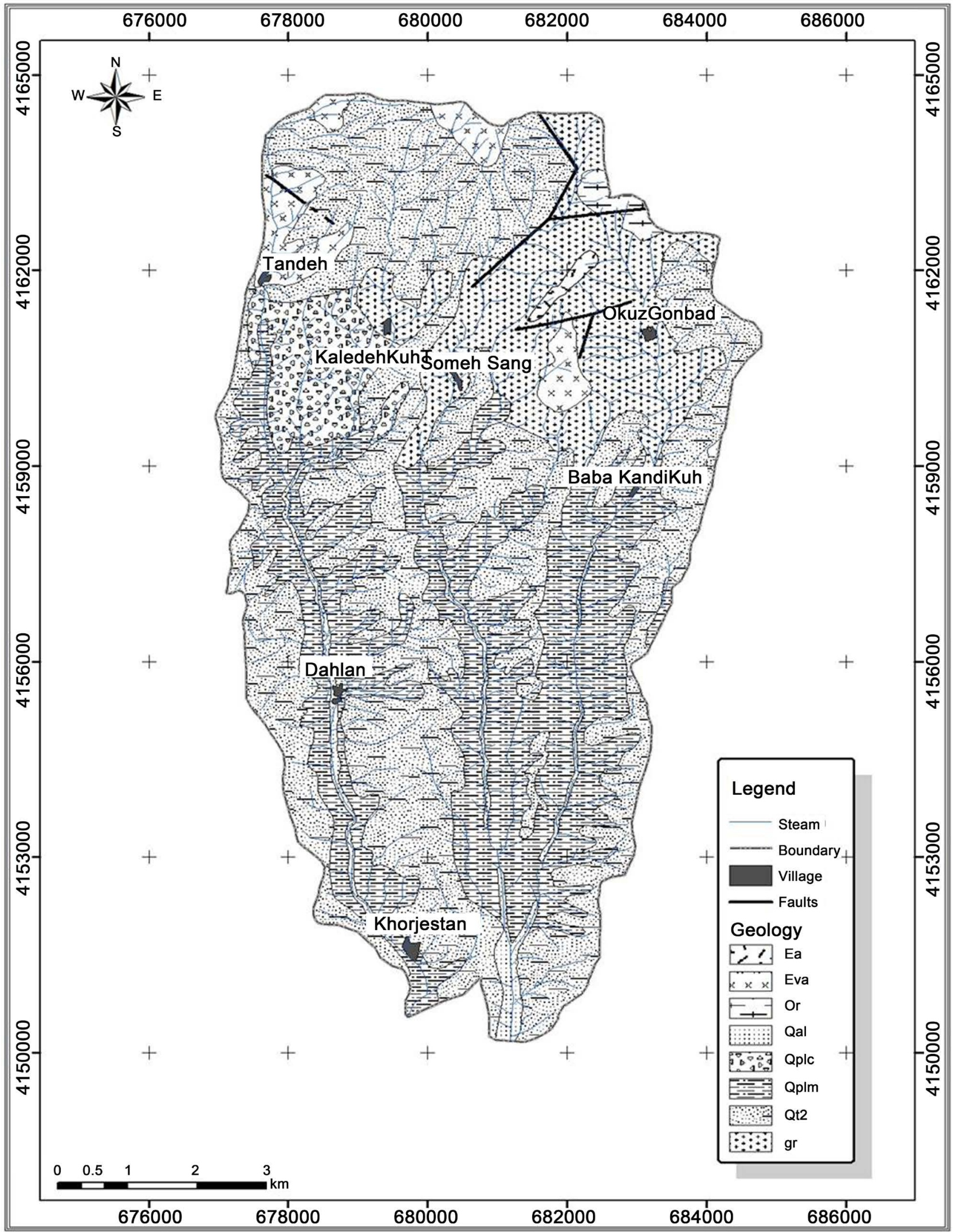

Figure 3. Drainage density on geological map. 
Table 1. Geological units resistance index [9].

\begin{tabular}{cccc}
\hline Rocks and sediments & Geological units & Resistance index & Area (\% of total area) \\
\hline Hard Rocks & gr & 4 & 14.26 \\
& $\mathrm{O}_{\mathrm{r}}$ & 1 & 0.68 \\
& $\mathrm{E}_{\mathrm{va}}$ & 3 & 0.68 \\
& $\mathrm{E}_{\mathrm{a}}$ & 2 & 3.67 \\
Soft Rocks (Unconsolidated Rocks) & $\mathrm{Qpl}^{\mathrm{c}}$ & 6 & 4.7 \\
& $\mathrm{Qpl}^{\mathrm{m}}$ & 9 & 27.56 \\
Old alluvial deposits & $\mathrm{Q}^{\mathrm{t} 2}$ & 8 & 46.5 \\
Recent alluvial deposits & $\mathrm{Q}^{\mathrm{al}}$ & 7 & 2.21 \\
\hline
\end{tabular}

elementary catchment depending on its drainage density [10], were prepared (Table 2).

The coefficient value for each lithological unit from which the emission risk is obtained, is determined by multiplying the erosion class according the drainage densityand the weighting factor [6]. Table 3 shows the calculated values and the erosion risk for different geological units of study area. The critical sediment source could be calculated based on the risk data. This table shows the erosion risk of slight, moderate, high, severe and very severe as $0.68 \%, 0.33 \%, 3.67 \%, 14.26 \%$ and $81.06 \%$ of total area, respectively. The data is presented as map of erosion risk and critical sediment source (Figure 4).

\subsection{BLM Model}

BLM methodology, initiated by Bureau of Land Management (BLM) of the United State of America, is mainly base on the erosion types. This model is integrated seven factors of surface erosion variable from (0 - 14), Litter covering the surface $(0-14)$, rock fragment $(0-14)$, superficial degradation $(0-14)$, rill erosion $(0-14)$, runoff sediments precipitation $(0-15)$ and gully erosion $(0-15)$; to calculate the Soil Surface Factor (SSF), which is the base for assessment of erosion intensity and erosion factor determination (Table 4). Every factor of this model was studied and mapped in GIS software to get the results as Table 5, Figure 5 and Figure 6. According to Table 5, the study area could be dissection in 3 major erosion risk, including moderate, high and severe with area of $32.1 \%, 42.96 \%$ and $24.94 \%$ respectively.

\section{Conclusion}

Fargas and BIM models are mostly used to determine erosion risk, erosion intensity and critical sediment source. Fargas model generally is more common, as it uses less factors, which are easy to produce the data. BLM model covers more components and needs data to be studied carefully and integrated to one aspect as soil surface factor. This study uses both model to evaluate erosion severity in the same area, in order to find the similarities and differences. The results show, generally there are similar classes between both model results, but deep investigation on the calculated classes area, re- 
Table 2. Erosion class based on drainage density.

\begin{tabular}{ccccc}
\hline Class & Geological Unit & Erosion degree & Drainage Density $\left(\mathrm{Km} / \mathrm{Km}^{2}\right)$ & Rating value \\
\hline 1 & $\mathrm{E}_{\mathrm{va}}$ & Very severe & 4.34 & 10 \\
2 & $\mathrm{E}_{\mathrm{a}}$ & Severe & 1.76 & 10 \\
3 & $\mathrm{O}_{\mathrm{r}}$ & Very severe & 2.72 & 10 \\
4 & $\mathrm{gr}$ & Very severe & 4.44 & 10 \\
5 & $\mathrm{Qpl}^{\mathrm{c}}$ & Very severe & 5.37 & 10 \\
6 & $\mathrm{Qpl}^{\mathrm{m}}$ & Very severe & 5.49 & 10 \\
8 & $\mathrm{Q}^{\mathrm{t}}$ & Very severe & 3.04 & 10 \\
\hline
\end{tabular}

Table 3. Classification of sediment emission risk.

\begin{tabular}{|c|c|c|c|c|c|c|c|c|}
\hline $\begin{array}{l}\text { Geological } \\
\text { unit }\end{array}$ & Lithology & $\begin{array}{l}\text { Resistance } \\
\text { index }\end{array}$ & $\begin{array}{c}\text { Area } \\
\text { (\% of total) }\end{array}$ & $\begin{array}{l}\text { Drainage } \\
\text { length }\end{array}$ & $\begin{array}{l}\text { Drainage Density } \\
\left(\mathrm{Km} / \mathrm{Km}^{2}\right)\end{array}$ & $\begin{array}{l}\text { Rating } \\
\text { value }\end{array}$ & $\begin{array}{l}\text { Coefficient } \\
\text { value }\end{array}$ & Risk \\
\hline $\mathrm{E}^{\mathrm{va}}$ & Andesitic lava, Tuff & 3 & 3.67 & 12.49 & 4.34 & 10 & 30 & High \\
\hline $\mathrm{E}^{\mathrm{a}}$ & Andesite, Andesitic basalt & 2 & 0.33 & 0.45 & 1.76 & 8 & 16 & Moderate \\
\hline gr & Granite & 4 & 14.26 & 49.6 & 4.44 & 10 & 40 & Severe \\
\hline $\mathrm{Qpl}^{\mathrm{c}}$ & Unconsolidated Conglomerate & 6 & 4.71 & 19.77 & 5.37 & 10 & 60 & Very Severe \\
\hline $\mathrm{Qpl}^{\mathrm{m}}$ & Sandy marl & 9 & 27.57 & 118.5 & 5.49 & 10 & 90 & Very Severe \\
\hline $\mathrm{Q}^{\mathrm{al}}$ & Alluvium & 7 & 2.32 & 25.1 & 13.85 & 10 & 70 & Very Severe \\
\hline
\end{tabular}

Table 4. The erosion risk based on the 7 factors (bureau of land management).

\begin{tabular}{cc}
\hline Sum 7 factors score & Erosion Risk \\
\hline $0-20$ & Low \\
$21-40$ & Moderate \\
$41-60$ & High \\
$61-80$ & Severe \\
$81-100$ & Very Severe \\
\hline
\end{tabular}

Table 5. Erosion risk in the study area based on SSF calculation.

\begin{tabular}{|c|c|c|c|c|c|c|c|c|c|c|}
\hline Class & \multicolumn{7}{|c|}{7 Factors of BLM } & Total score & Risk & Area ( $\%$ of total Area) \\
\hline E1 & 6 & 6 & 6 & 6 & 7 & 7 & 4 & 42 & High & 18.59 \\
\hline E2 & 6 & 6 & 6 & 6 & 8 & 8 & 0 & 40 & Moderate & 13.12 \\
\hline E3 & 4 & 4 & 4 & 4 & 5 & 5 & 5 & 31 & Moderate & 18.98 \\
\hline E5 & 8 & 8 & 8 & 8 & 11 & 11 & 8 & 62 & Severe & 7.72 \\
\hline E6 & 8 & 8 & 8 & 8 & 11 & 11 & 11 & 65 & Severe & 17.22 \\
\hline
\end{tabular}




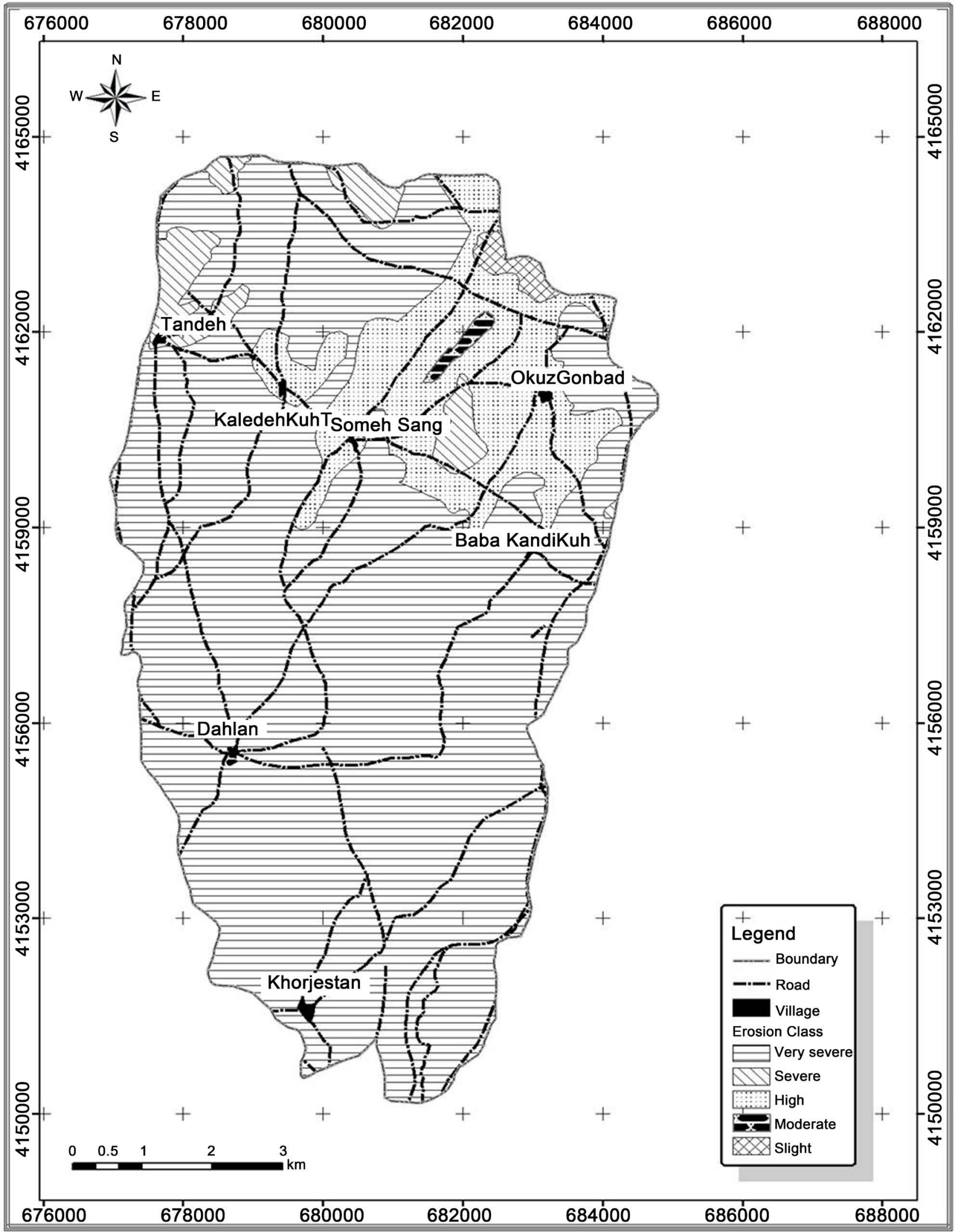

Figure 4. Risk of erosion based on Fargas method. 


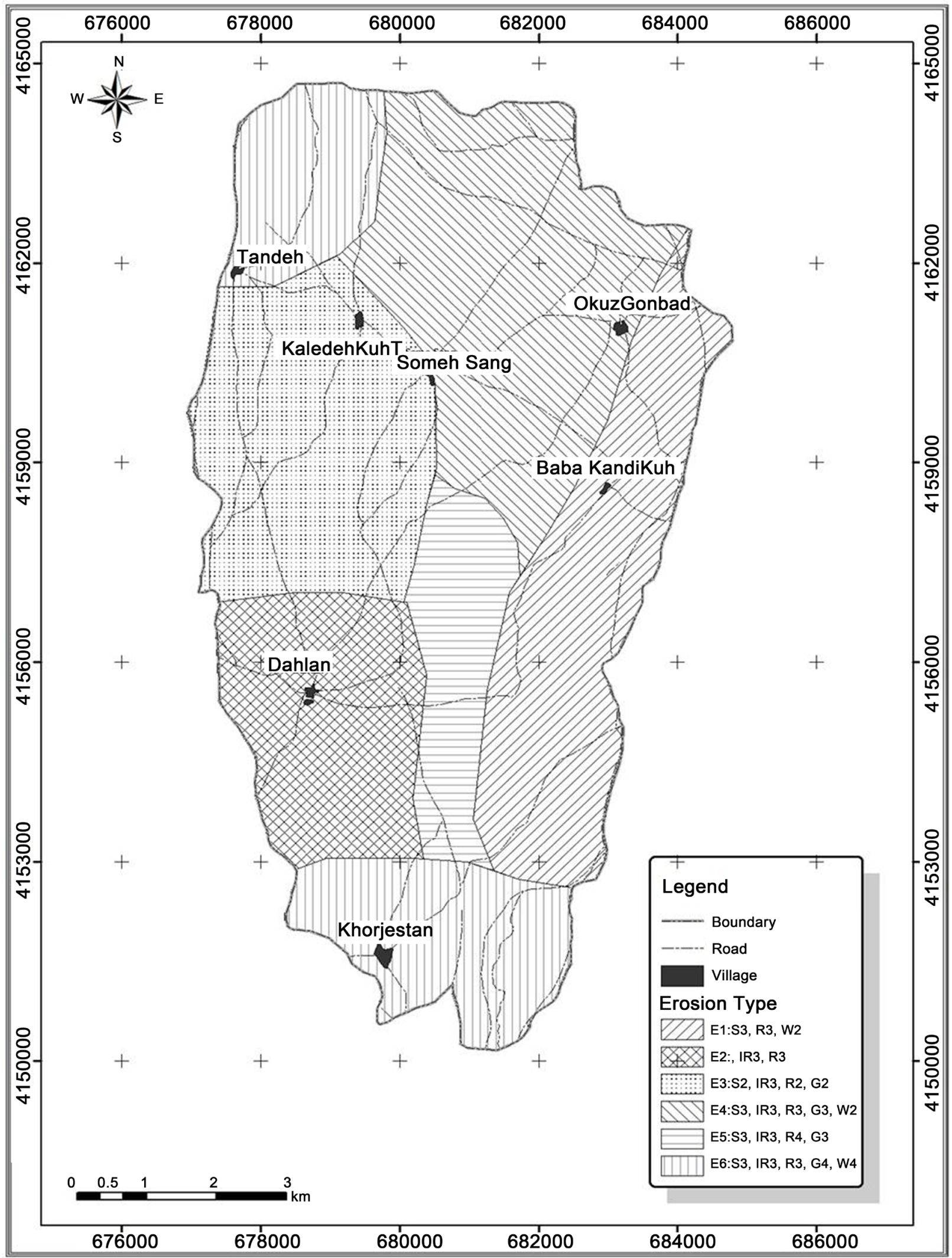

Figure 5. Erosion types in the study area. 


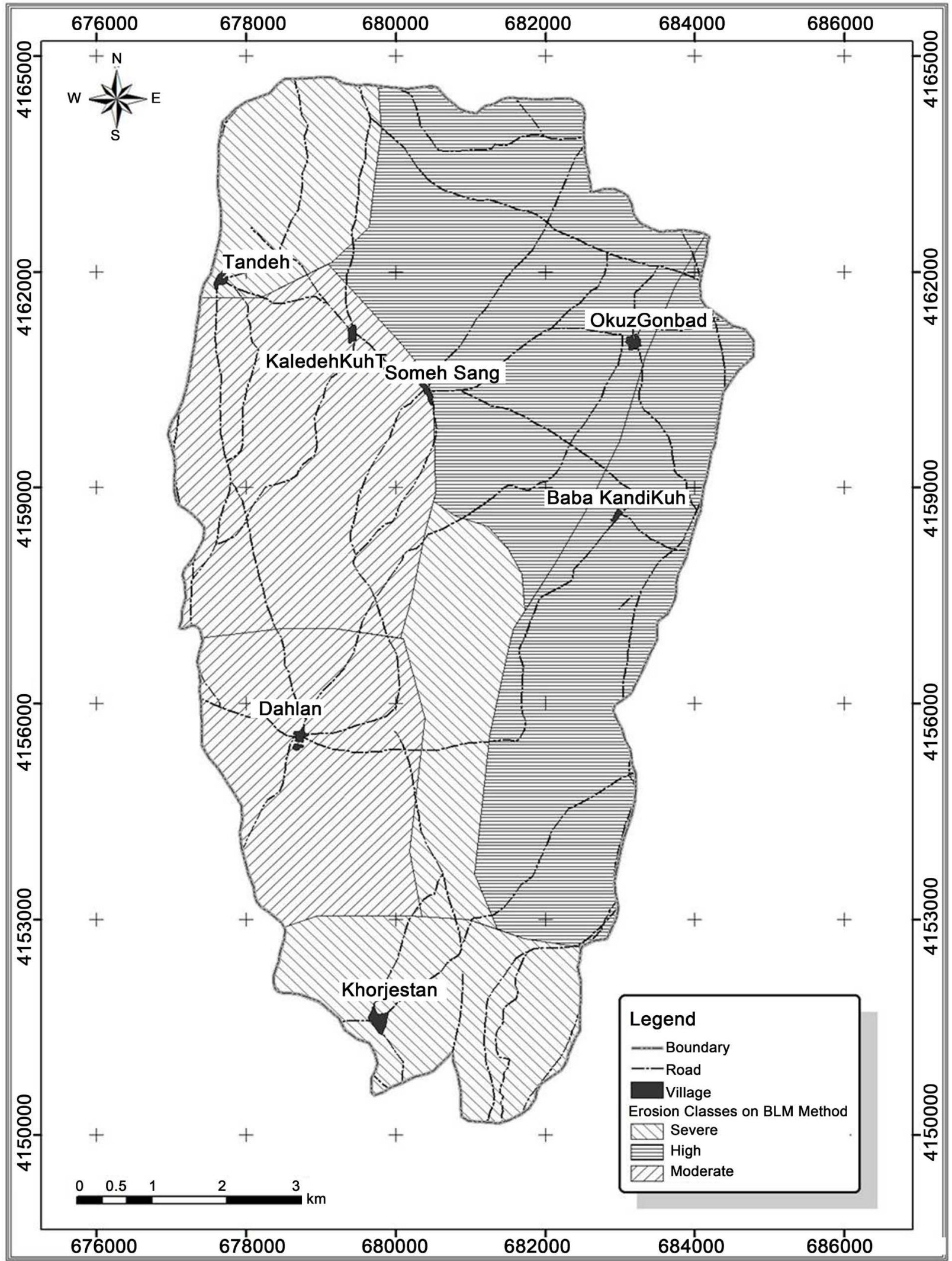

Figure 6. Erosion risk based on BLM method. 
veals that there are no enough coverage between the final outcomes of these models. Fargas model predicts $3.67 \%, 14.26 \%$ and $81.06 \%$ of the area susceptible for high, severe and very severe erosion respectively; whilst, referring to BLM model outcome, $42.96 \%$ area has high sensitivity; $42.96 \%$ and $24.94 \%$ of the area have high and severe sensitivity for erosion, respectively. Furthermore, both models show the same severity for around $18 \%$ of the study area. This means, by applying two models in the same study and making comparison between the products, we find advantages and disadvantages of the methods, and understand the shortage of any model, or any faults during the study. Finally it is recommended to never rely on one of these models, or maybe any others, even very common methods.

\section{Acknowledgements}

This study is based on the research plan of "Evaluation of Sediment Production intensity in Different phases of basic studies (Case Study, North of Hashtrood City)" which is supported by Islamic Azad University (IAU), Ahar Branch. We are thankful to the chancellor, research deputy and all of the staffs of the university which gave support us in this issue.

The author acknowledges the immense help received from the scholars whose articles are cited and included in references of this manuscript. The author is also grateful to authors/editors/publishers of all those articles, journals and books from where the literature for this article has been reviewed. The anonymous editor(s) of this paper is also respected for their comments.

\section{References}

[1] Soil Science Society of America (2001) Glossary of Soil Science Terms. Soil Science Society of America, Inc., Madison.

[2] Moran Lu, H. and Prosser, C.J. (2005) Modeling Sediment Delivery Ratio over the Murray Darling Basin. Environmental Modelling \& Software, 21, 1297-1308.

https://doi.org/10.1016/j.envsoft.2005.04.021

[3] Santhi, C., Srinivasan, R., Arnold, J.G. and Williams, J.R. (2006) A Modeling Approach to Evaluate the Impacts of Water Quality Management Plans Implemented in a Watershed in Texas. Environmental Modelling \& Software, 21, 1141-1157. https://doi.org/10.1016/j.envsoft.2005.05.013

[4] Miller, S.N., Semmens, D.J., Goodrich, D.C., Hernandez, M., Miller, R.C., Kepner, W.G. and Guertin, D.P. (2007) The Automated Geospatial Watershed Assessment Tool. Environmental Modelling \& Software, 22, 365-377. https://doi.org/10.1016/j.envsoft.2005.12.004

[5] Clean Water Services (2008) Erosion Prevention and Sediment Control Planning and Design Manual.

[6] Poesen, J., Nachtergaele, J., Verstraeten, G. and Valentin, C. (2003) Gully Erosion and Environmental Change: Importance and Research Needs. Catena, 50, 91-133. https://doi.org/10.1016/S0341-8162(02)00143-1

[7] Cheng, H., Zou, X., Wu, C., Zhang, C., Zheng, Q. and Jiang, Z. (2007) Morphology Parameters of Ephemeral Gully in Characteristics Hillslopes on the Loess Plateau of China. Soil and Tillage Research, 94, 4-14. https://doi.org/10.1016/j.still.2006.06.007 
[8] Fargas, D., Martínez-Casanovas, J.A. and Poch, R. (1997) Identification of Critical Sediment Source Areas at Regional Level. Journal of Physics \& Chemistry of the Earth, 22, 355-359. https://doi.org/10.1016/S0079-1946(97)00158-4

[9] MOPT (1992) Propuesta del proyecto de directrices. Cuenca del Ebro. Confederación Hidrográfica del Ebro-MOPT.

[10] Stroosnijder, L. and Eppink, L.A. (1993) Principles of Soil and Water Conservation. Lecture Notes of Course K200-500/510. WAU, Wageningen.

Submit or recommend next manuscript to SCIRP and we will provide best service for you:

Accepting pre-submission inquiries through Email, Facebook, LinkedIn, Twitter, etc. A wide selection of journals (inclusive of 9 subjects, more than 200 journals)

Providing 24-hour high-quality service

User-friendly online submission system

Fair and swift peer-review system

Efficient typesetting and proofreading procedure

Display of the result of downloads and visits, as well as the number of cited articles Maximum dissemination of your research work

Submit your manuscript at: http://papersubmission.scirp.org/

Or contact ojg@scirp.org 